\title{
COACHING PROCESS AND ITS INFLUENCE ON EMPLOYEES' COMPETENCIES IN THE HOSPITALITY SECTOR - CASE STUDY
}

\author{
Anna Dolot*
}

\begin{abstract}
Background. Coaching is rarely used in the hospitality sector, a branch facing numerous problems in the area of Human Resource Management (HRM). Meanwhile, owing to its uniqueness and distinctive features, it contributes to complex competency development, bringing many benefits to HRM.

Research aims. Some questions arise: how is the coaching process implemented in the hospitality sector; which of its elements (setting a coaching goal, coach's active listening, asking questions, providing feedback, or building creative atmosphere) have the biggest influence on competency development? Moreover, from the point of view of a gap in the conducted research, it would be useful to learn which competencies are developed with the help of coaching in the hospitality sector.
\end{abstract}

Methodology. Due to the rarity of coaching in the hospitality sector a case study method has been used.

Key findings. Coaching is rarely used in the hospitality sector. The most important element of the coaching process is posing thought-provoking questions by a coach both in the realised as well as in the ideal coaching process. Coaching is most helpful in the development of the following competencies: more effective management of one's team, communication with other employees, and team work.

Keywords: coaching, competencies, development, hospitality.

* Cracow University of Economics. E-mail: anna.dolot@uek.krakow.pl

This article was financed with subsidies for maintaining the research capacity granted to the Cracow University of Economics. 


\section{INTRODUCTION}

Taking into account constant and frequently dynamic changes taking place in the environment, continuous employee training is indispensable. Under favourable circumstances, training has an important dual function of utilisation and motivation (Graham \& Bennett, 1998, p. 283). By improving employees' ability to perform the tasks required by the company, training allows better use to be made of human resources. There are several methods of employee training, and coaching is one of them. It is a result-oriented, systematic process in which the coach facilitates the enhancement of life experience and goal-attainment in the personal and/or professional lives (Grant, 2003, p. 254). The staff members who benefit from coaching are most often managers, that is why coaching is defined as a partnership between a management-level client and a coach hired by an organisation to assist the employee in becoming a more effective and successful manager (Hannafey \& Vitulano, 2013).

Coaching is implemented in many branches of industry, for example, automotive (Branch \& Smith, 1992), healthcare and pharmaceutical (Henochowicz \& Hetherington, 2006; Ainsworth, 1995; Marton \& Pister, 2016; Dahling et al. 2016), telecommunication (Eaton \& Brown, 2002), and banking (Clark, 1998; Hippensteel et al., 1999). However, there are very few publications concerning coaching implementation and its benefits in the hospitality sector. One can find publications which describe coaching as a method used in the hospitality sector, and emphasise at the same time a lack of appropriate understanding of this method (Krazmien \& Berger, 1997).

Meanwhile, the hospitality sector faces numerous problems concerning HRM:

- difficulties in recruiting and keeping employees resulting in staff shortages (Zhang Qiu \& Lam, 2004),

- $\quad$ low wages (Price, 1994; Poulston, 2008; Grobelna, 2015),

- working in shifts, working hours and days which make it difficult to establish a good work-life balance (Pratten, 2003),

- conflicts between employees and their superiors (Page et al., 2009),

- a negative image (Dickinson \& Ineson, 1993).

Irregularities concerning the HRM branch influence the employees' attitude towards their tasks, which has an impact not only on relations 
between co-employees, but also between employees and customers, consequently having an impact on service quality. Consequently, those irregularities within the area of HRM are detrimental to all the parties in the industry: employees, employers, and customers. Therefore, it seems crucial to implement such human resources management, so that it has a positive influence on employees, their competencies, and finally on their attitude towards customers and towards each other.

The aim of this article is to analyse the coaching process and the influence of its particular elements on the competency development of employees employed in hotels.

The article consists of the following parts: explaining what competencies are, how they coexist with other behaviour patterns at work, and analysing the coaching process. Next, the research methods are introduced and the findings are presented. The article ends with a discussion and conclusions, followed by limitations of the study and recommendations for further research.

\section{THEORETICAL BACKGROUND}

\section{Competencies and their relation to behaviour patterns occurring at work}

There is a growing interest in focusing on the competencies that individuals need in order to perform jobs, rather than on the tasks, duties, and responsibilities composing a job (Mathis \& Jackson, 2000). The concept of competency-based human resources has gone from a new technique to common practice in the 35 years since D. McClelland (1973) first proposed them as a critical differentiator of performance (Boyatzis, 2008, p. 5). He linked competencies with action, performing particular tasks and their outcome (McClelland, 1973). The next researcher who focused on the concept of competency was R. Boyatzis. In 1982, for the first time, he tried to define this term. According to him, competency comprises such elements as motives, features, abilities, self-image or social roles, and knowledge used (Boyatzis, 1982). In his opinion, professional competency represents the potential, an ability to perform something. An individual set of competencies reflects the capabilities of a person - competencies are identified with the qualities of an employee who really does a good job. 
The literature most frequently gives definitions which point to knowledge, abilities and attitude, or certain personality features, as the key components of competencies (Yuvaraj, 2011; Hornby \& Thomas, 1989). However, it should be emphasised that one can also encounter other factors added to these definitions, e.g. motivation (Jia \& Fan, 2008), self-evaluation (Spencer \& Spencer, 1993), intellectual potential (Gupta \& Roos, 2001), self-concept (Hooghiemstra, 1992), health state, talents, internal motivation, or predispositions (Oleksyn, 2006).

Woodruffe (1991) suggests that the term competency is used to refer to two factors: 1) areas of work at which the person is competent, the so-called "areas of competence" and the proven ability to perform a job competently (i.e. to the standards required in employment), and 2) the sets of behaviour the person must display in order to perform the tasks and functions of a job with competence. He also adds that each competency is composed of a cluster of behaviours (Woodruffe, 1993). These are the behaviours of the high performer. A competency is behaviour that allows a person to perform competently. Behind it, there must be both the ability and desire to behave in that competent way. Competencies can provide a common language within organisations to describe both desired skills and behaviours required to achieve desired organisational outcomes (Holbeche, 2009). From the managerial and economical point of view, the very fact of a given employee being equipped with knowledge, experience, personality features or other ones mentioned in the definitions pertaining to elements is not as essential as is their implementation reflected in this employee's behaviour, and finally the outcomes that this behaviour shall bring the organisation.

It is characteristic that competencies coexist with a job situation, which defines when a desired performance or action is required, and that competencies are observable (Hoffmann, 1999), similarly to human behaviour.

Competency development seems to be a challenge. While knowledge and ability acquisition constitutes the aim of training methods, changing traits or behaviours which, with time, become habits is difficult. As specialists emphasise, a trait is a relatively enduring characteristic of an individual's behaviour that cannot be easily changed through training (Berge et al., 2002). Thus, it seems crucial to use training methods which, by way of a regular process, make it possible not only to gain knowledge and skills, but also to change those undesirable behaviours. 


\section{Coaching and its process}

In the literature, coaching is described relatively often, it also enjoys the interest of practitioners. Coaching is essentially a conversation - a dialogue between a coach and a coachee - within a productive, result-oriented context. It involves helping individuals access what they know (Zeus \& Skiffington, 2001). In the coaching process, it is essential to focus on a coachee's behaviours - before the process starts and when it is completed. Coaching brings behavioural change and helps people understand how their cognitive and emotional reactions can interfere with personal effectiveness, performance, and well-being (Bluckert, 2005b). Sustained behaviour change is the ultimate goal of most executive coaching engagements (Brotman et al., 1998). Coaching has become more widely used for senior executives who may benefit from an independent view on their own performance (Guest \& King, 2005).

A coach plays an important role in the coaching process. This person is supposed not to control but to help the coachee develop new capabilities, see new perspectives, and/or create new worlds of opportunities (Nielsen \& Nørreklit, 2011). She or he will guide individuals towards increased awareness of how their thoughts and emotional reactions lead to problematic behaviours in the workplace (Bluckert, 2005b). The coach helps recognise the coachee's strengths and weaknesses, she or he is a facilitator not an owner of change who helps set conditions and circumstances that help the coachee's change, she or he tries to show which behaviours are unlikely to lead to goals (Ulrich, 2008).

There are research studies confirming the effectiveness of coaching. Some researchers emphasise the influence of coaching on the coachee, e.g. in the context of developing chosen competencies, changing one's attitude, developing one's personal qualities (Evers et al., 2006; Jarvis, 2004). Coaching is also effective in correcting and improving poor performance (Gravina \& Siers, 2011), it has significant positive effects on performance and skills, well-being, coping, work attitudes, and goal-directed self-regulation (Theeboom et al., 2014), conflict resolution in the workplace (Anderson et al., 2009), generating improvements in individuals' performance, increasing openness to personal learning and development, and helping in identifying solutions to specific work-related issues (Wilson, 2004).

Numerous positive outcomes of coaching may result from its specific procedure and assumptions which it is characterised by. 


\section{Setting goals}

Goals provide a standard of performance, a basis for planning and management control, guidelines for decision-making and justification for actions taken (Mullins, 1996). Goal setting focuses attention and generates behaviour as it directs thoughts and actions (Ives, 2008). Coaching is essentially a goal-oriented process. It commences with agreeing on the goals for the programme (Rider, 2002). Numerous authors emphasise the role of goal-setting in coaching (Smither, 2011; Crane, 2001; Dahling et al., 2016). Alexander and Renshaw (2005) stress the importance of setting goals to give purpose and direction to the coaching session and to prevent it from becoming "a meandering natter". Goal setting also constitutes an important stage in many models of coaching (Whitmore, 2009; Dembkowski et al., 2006).

It is worth stressing that most often the realisation of the goal defined by the coachee consists in undertaking particular actions, which requires implementing particular behaviours. This element differentiates coaching from other methods of employee training - it does not focus on gaining new knowledge or abilities by the coachee, but on using the knowledge and abilities they already have by implementing particular behaviours in everyday situations, behaviours which contribute to achieving the goals set.

\section{Communication geared towards constructive questions and constructive feedback}

Communication in coaching plays a leading role. The coach can use several more or less directive communication tools. The literature concentrates mainly on two of them: posing questions by the coach (linked with active listening) and giving feedback.

Posing questions by the coach seems to be an element which to a significant extent differentiates this method of employee training from other ones. Effective questioning lies at the very heart of the coaching conversation (Grant \& O'Connor, 2010). Coaching consists more in questioning than suggesting ready solutions and sharing the coach's knowledge and experience. He engages in a collaborative alliance with the individual to establish and clarify purpose and goals and to develop a plan of action to achieve these goals. The coach assists, supports, and encourages individuals to find these answers (Zeus \& Skiffington, 2001). 
Thus, questions are used during the whole collaboration process between the coach and the coachee. Effective questions shall increase motivation, develop the comprehension process, have a positive influence, increase faith in one's abilities, especially in a situation of change, as well as help the individual realise their set goals (Grant \& O'Connor, 2010). Powerful questioning is the ability to ask questions that reveal the information needed for maximum benefit to the coaching relationship and the client (Auerbach, 2005). Similarly, other specialists state that questions asked the individual by their coach are the key element of coaching (Griffiths, 2005; Barlow, 2005, Mertel, 2010).

Questions aim at raising the coachee's awareness and at deep listening by the coach (Bluckert 2005b; Ellinger \& Bostrom, 1999). Thanks to this, the coachee finally defines a previously-set goal which they would like to achieve by means of coaching, analyses the situation they find themselves currently in, can define their strengths and opportunities that the environment offers, as well as analyse the areas that need to be developed and threats posed by the environment in which the coachee acts. Identifying resources and on the basis of formulating specific action plans seems to be an inseparable element of the whole coaching process (Grant, 2013). Resource analysis (similarly to setting goals to be realised with the help of coaching) constitutes an important stage in coaching models (Whitmore, 2009; Dembkowski et al., 2006). The coach's additional role is not only the analysis of one's resources but also their activation (Greif, 2013).

The role of feedback is emphasised by many specialists (Grant, 2013; Dahling et al. 2016; Wheeler, 2011). Feedback explains why behaviours are effective or ineffective, quotes specific examples, allows the person receiving feedback to comment, provides alternative positive behaviours, maintains esteem of those involved (Latham \& Marchbank, 1994). Feedback may have a coach-generated or self-generated character (Griffiths, 2005). The latter is possible thanks to the abovementioned inspirational questions. However, it is stressed that providing feedback is one of the most effective, as well as difficult coaching behaviours (Marsh, 1992; Ellinger \& Bostrom, 1999). Preferable feedback is clear, specific and understandable (Williams, 2002). Feedback to be constructive needs to recognise external causes where they have a deleterious effect, and the sender of the feedback needs to be clear about the message that is being sent. It also needs to be delivered in a supportive way (London, 1997; Williams, 2002). 
The coaching process shows how significant the relation coach-coachee is. This relation is based on trust and confidentiality (Boyce et al., 2010), respect (Whitworth et al., 1998) and good match (Joo, 2005). When trust is present, clients are more likely to share sensitive information and coaches have greater influence over their clients (Gyllensten \& Palmer, 2007; Kampa-Kokesch \& Anderson, 2001). A good match or fit between a client and a coach is critical to the development of a quality coaching relationship (Joo, 2005). Many specialists emphasise the role and elements of building the relation between the coach and their client (Day, 2010; Bluckert, 2005a).

The above analysis of the coaching process and its particular elements leads to posing the following research questions:

1. Does coaching develop hotel employees' competencies?

2. What is the coaching process in particular hotels like? Were the key elements of coaching, i.e. goal-setting, environment and resource assessment, two-way communication based on questions and feedback, implemented in synergy?

3. Which of the coaching elements: goal-setting, posing questions, active listening, providing feedback, or building the coach coachee relation influences competency development the most in the opinion of the respondents?

\section{RESEARCH METHODOLOGY}

The questionnaires were sent to 43 four and five-star hotels. The choice of the hotel category was deliberate. Pilot studies conducted earlier showed that coaching is used relatively rarely in the hospitality sector and that it is used mainly in chain hotels which are minimum four-star ones. 33 hotels took part in the research. The response rate was $77 \%$.

It turned out that coaching was used in 5 out of 33 researched hotels. This means that merely $15 \%$ hotels use coaching as a competency development method. In order to collect information necessary to realise the research set goals, the decision was taken to directly interview all coachees. If the coachee occupied a different position than a hotel manager (meaning the highest position in the organisational structure), the questionnaires were also directed to their immediate superior. Immediate superiors took part in the research due to the fact that: 
- They are responsible for training and development of their employees;

- They have more opportunities to notice potential changes (their direction and intensity), or their lack in the behaviour of coached employees, and changes pertaining to hotel functioning.

It was not always possible to get familiar with the opinion of each coachee's superior. This situation occurred when:

- The participant of the coaching process was a hotel manager. It meant that they did not have any immediate superior or this superior was a person living abroad or a person so high in the hotel hierarchy that it was physically impossible to reach them;

- It derived from the character of coaching. The most interesting case was the one where in one of the hotel chains the coaching rule is that neither an immediate superior nor a hotel manager knows which employee benefits from coaching. Coaching is performed by an internal coach, employed in the hotel structure, but not being an immediate superior of the employees coached. In this situation it was not possible to interview immediate superiors as they simply did not know which employee benefits from the coach's services. It is a very interesting solution from the point of view of coaching, geared towards employees' needs, giving an opportunity to build an atmosphere based on openness and trust.

Thus, different questionnaires were prepared for these groups (coachee and coachee's superior). The method of a direct interview was chosen. 19 coachees were identified and all of them were interviewed. Additionally, 10 immediate superiors of the employees coached were interviewed as well. All in all, 29 exhaustive interviews were done, questioning employees in hotels which implement coaching.

Research has a character of a case study which is a popular method in management research (Karami et al., 2006; Wallace et al., 2011). Case study is a method recommended by many experts (Robson, 2002; Czakon, 2011), and it is the favoured methodology for understanding complex, psychodynamic processes in organisations (Neumann \& Hirschhorn, 1999). Although the number of the interviews run may raise our concern, it shall be emphasised that, firstly, the phenomenon is rare (probably due to the problems of HRM in the hospitality sector described above), and secondly, the literature regards the number of 
individual, advanced interviews ranging from 15 to 30 as sufficient to conduct the research effectively (Mariampolski, 2001).

\section{RESEARCH RESULTS}

\section{Coaching process}

As it was pointed out in the theoretical part of this article, coaching stands out from other methods of employee development by synergic implementation of the following elements: goal-setting, two-way communication, where questioning by the coach plays a key role, together with their active listening and constructive feedback and a partner-like relationship between the coach and the coachee. In order to verify the practice of the coaching process in all researched subjects, its course was scrutinised.

As far as the goals are concerned, it should be emphasised that in $100 \%$ of the cases coaching goals were set at the beginning of the coaching process, which is a very important element and positively verifies the fulfilment of the first condition.

The respondents were asked who defined their goals: whether they defined them on their own (the coachee), if they were set by the coach, or together (the coachee and the coach), or maybe the goal was imposed by the coach. The research results show that most often the goal was set together by the coachee and the coach (58\%), the coach defined the goal in $26 \%$ of the cases, the coachee defined the goal in $16 \%$ of the cases and in the minority of the cases, i.e. $11 \%$ of them, the goal was defined by the coachee's immediate superior. The most frequent situation (53\%) was the one in which the coach was the coachee's immediate superior. On the other hand, employing the external coach turned out to be much less frequent (only 11\%). When there was an external coach (i.e. employed in the hotel structures or in a given hotel chain) who was not the coachee's immediate superior (37\% of the cases), the role of the coach was most frequently played by: an employee representing an HR department (e.g. Regional HR Manager or HRM Department Manager), or an employee occupying a higher position than the coachee's immediate superior.

The coaching goal content was analysed. The answers to open questions regarding coaching goals were grouped in five categories, 
the sixth one constituting other, individually mentioned goals. The most frequent coaching goal was the development of human resources management capabilities (79\%). In this case, the respondents questioned pointed to such areas as: efficient task distribution, improvement of relations with a managed team. The essential goal was to prepare a given employee to take a higher position in the hotel structure (26\%). In this case, coaching served to develop several competencies. It is noticeable that though coaching was in each case the method of employee training, the goal pertaining to private life occupied the third place ( $21 \%$ of the cases). It is a valuable remark, as on the one hand, it shows that a given employee can count on help at work also in case of personal problems, and, on the other hand, it confirms that coaching is a method which influences the employee's development and their competencies in a complex way. The development of selling competencies was the goal in $16 \%$ of the cases, and preparing for the organisational change constituted $11 \%$ of the cases. There were also many answers constituting rarely occurring goals (most often isolated ones). They were classified as "others". Although this category constituted $42 \%$ of all the cases, none of the answers exceeded $5 \%$. In this case, there were the following goals:

- competency development concerning a very particular specialisation (e.g. budget planning);

- working on employees' attitudes (e.g. higher self-esteem, changing their attitude towards a particular issue, preparing for a potential role conflict linked with future promotion).

Later on, there was an attempt to identify elements constituting the coaching process. The analysis of the coaching process in the questionnaire meant, first of all, questions concerning the occurrence of each element. In $100 \%$ of the cases, questioning, i.e. the most characteristic element of this method, was implemented. In the majority of the cases (95\%) one could also identify: the client's resource analysis, the coachee's environment analysis. Feedback was provided in $95 \%$ of the cases. It is worth emphasising in this place that in practice one can encounter situations where the coach assumes the communication strategy based entirely on questioning, deliberately eliminating feedback.

At the end of the questionnaire, there was a control question by means of which the respondents were asked to list the elements occurring during the coaching process. The response structure read as follows: in $100 \%$ of the cases the coach was concerned with defining 
coaching goals, posed inspiring and creative questions and built an atmosphere of partnership. In $95 \%$ of the cases the coach provided feedback and listened actively. Thus, it can be assumed that in the researched hotels, the coaching process proceeded with the synergic implementation of its key features: goal setting, environment and resource analysis, two-way communication based on questioning and feedback (positive answer to the second research question).

The answer to the third research question was also crucial. The question concerned the importance of particular elements of the coaching process and their influence on competency development.

In the further part of the questionnaire aimed at the coachee, the coaching process was analysed once again. The coaching elements defined earlier - goal setting, questioning (including the coachee's resource and environment analysis), providing feedback - were accompanied with active listening and building a relationship based on cooperation and trust. During the research, coaching participants were asked to allocate 100 points to the above-mentioned elements, assessing at the same time their influence on their competency development. In this way, the coachees defined the importance of particular elements in the realised coaching process and their influence on competency development, presented in Table 1 . The table shows that the most important element of the coaching in question was posing thought-provoking questions which enhanced solution seeking. As it is presented in Table 1, the employees describing the coaching process granted the biggest importance to the element "posing questions by the coach" (30.5\%).

Table 1. The importance of particular coaching elements in the coachee's competency development in the coaching processes realised

\begin{tabular}{|c|l|c|c|c|c|c|c|}
\hline \multicolumn{7}{|c|}{ Chosen descriptive statistics } \\
\hline No. & $\begin{array}{l}\text { Particular } \\
\text { elements }\end{array}$ & $\begin{array}{c}\text { No. of } \\
\text { cases }\end{array}$ & Average & Median & $\begin{array}{c}\text { Minimal } \\
\text { value }\end{array}$ & $\begin{array}{c}\text { Maximum } \\
\text { value }\end{array}$ & SD \\
\hline 1. & Setting a coaching goal & 19 & 15.0 & 10.0 & 0.0 & 30.0 & 9.1 \\
\hline 2. & Coach's active listening & 19 & 19.7 & 20.0 & 5.0 & 40.0 & 9.6 \\
\hline $\mathbf{3 .}$ & $\begin{array}{l}\text { Posing thought-pro- } \\
\text { voking questions }\end{array}$ & $\mathbf{1 9}$ & $\mathbf{3 0 . 5}$ & $\mathbf{3 0 . 0}$ & $\mathbf{1 0 . 0}$ & $\mathbf{5 0 . 0}$ & $\mathbf{1 1 . 0}$ \\
\hline 4. & Providing feedback & 19 & 19.2 & 15.0 & 10.0 & 50.0 & 9.5 \\
\hline 5. & $\begin{array}{l}\text { Building creative atmo- } \\
\text { sphere }\end{array}$ & 19 & 15.5 & 10.0 & 0.0 & 50.0 & 13.8 \\
\hline
\end{tabular}

Source: own research. 
Additionally, the respondents were asked to envisage such coaching which they would describe as the most effective one (the best one), and to allocate 100 points to the same categories. The question was posed due to the fact that the coaching participants were already familiar with the coaching process and had their opinion on what could be more beneficial to them. Their answers are presented in Table 2.

Table 2. The importance of particular coaching elements in competency development in an ideal coaching process (a hypothetical question)

\begin{tabular}{|c|l|c|c|c|c|c|c|}
\hline \multicolumn{7}{|c|}{ Chosen descriptive statistics } \\
\hline No. & $\begin{array}{l}\text { Particular } \\
\text { elements }\end{array}$ & $\begin{array}{c}\text { No of } \\
\text { cases }\end{array}$ & Average & Median & $\begin{array}{c}\text { Minimal } \\
\text { value }\end{array}$ & $\begin{array}{c}\text { Maximum } \\
\text { value }\end{array}$ & SD \\
\hline 1. & $\begin{array}{l}\text { Setting a coaching } \\
\text { goal }\end{array}$ & 19 & 15.5 & 15.0 & 0.0 & 40.0 & 9.5 \\
\hline 2. & $\begin{array}{l}\text { Coach's active } \\
\text { listening }\end{array}$ & 19 & 20.3 & 20.0 & 0.0 & 40.0 & 10.1 \\
\hline 3. & $\begin{array}{l}\text { Posing } \\
\text { thought-provoking } \\
\text { questions }\end{array}$ & $\mathbf{1 9}$ & $\mathbf{3 2 . 4}$ & $\mathbf{3 0 . 0}$ & $\mathbf{2 0 . 0}$ & $\mathbf{5 0 . 0}$ & $\mathbf{1 0 . 5}$ \\
\hline 4. & Providing feedback & 19 & 18.7 & 20.0 & 0.0 & 30.0 & 8.0 \\
\hline 5. & $\begin{array}{l}\text { Building creative } \\
\text { atmosphere }\end{array}$ & 19 & 13.2 & 10.0 & 0.0 & 50.0 & 11.4 \\
\hline
\end{tabular}

Source: own research.

As it is shown in Table 2, an ideal coaching process for the respondents is still the one in which posing questions is the element contributing the most to competency development. This element is even regarded as the key one to a minimally bigger extent (1.8\%).

The above data let us relate to the third research question posed: which element of coaching influences competency development the most, in the respondents' opinion: goal setting, questioning, active listening, providing feedback, or building good relations between the coach and the coachee? The results placed in Table 1 and 2 show that in the respondents' opinion questions constituted (and would constitute if the coachee could change the structure of the process) the most helpful element of the coaching process geared at competency development. 


\section{The influence of coaching on competency development}

The assessment of the influence of coaching on competency development was performed in two ways: the coaching process was assessed by the coachees and their immediate superiors as people having the best picture of their employee's behaviour change, both positive and negative, or alternatively lack of any change.

\section{The coachee's perspective}

Coaching effects from the coachee's perspective were measured by the following variables:

1. The coachee's assessment of coaching influence on competency development;

2. Achieving coaching goals;

3. Defining the areas where coaching proved helpful.

Referring to particular variables, one can notice the following:

Re: $1.100 \%$ of the respondents researched confirmed that coaching contributed to their competency development.

Re: $2.100 \%$ of the respondents researched gave a positive response to a question if achieving the set goal was the outcome of coaching.

Re: 3. 100\% employees occupying managerial positions (18 cases) said that coaching helped them manage their teams more effectively, thus contributing to the development of their managerial competencies. As many as $95 \%$ of the respondents noticed improvement in the area of communicating with co-employees, that is improvement of the competency concerning interpersonal communication. No fewer than $84 \%$ of them remarked that coaching contributed to work efficiency in the team where a given coachee works. The next benefit is more confidence in one's strengths and capabilities. Moreover, 74\% of the responses pointed to: raising a coachee's awareness about what contributes to their effectiveness, more willingness to focus on personal development, better individual work effectiveness of a given coachee and improvement in customer service. It is significant that no respondent ticked the answer "Coaching has not helped me with anything". It means that each respondent developed at least one competency. Many respondents answered an open question "What was the other positive effect of coaching?" The following answers were given: 
- "More trust towards X (a respondent's immediate superior) as a superior. Help in professional and personal problems".

- "Better understanding of the communication process concerning the employees. Understanding that everyone has a different perspective".

- "Improving the relations with an immediate superior-coach, an opportunity to express personal opinions, more openness".

- "Developing ties between the coach and a coachee, better, more partnership-like and friendly relations".

- "I've succeeded in the development of three different people".

- "Coaching of one person motivates the others who also want to be coached".

- "More attention paid to employees' needs, bigger business awareness, better human resources management, more frequent conversations with employees, being with them".

- "More self-confidence at work; competency development. I know what to do so that people have better working conditions".

- "More self-confidence in presenting one's views".

\section{Immediate superiors' assessment of coaching influence on competency development}

The other source of data concerning coaching efficiency as a method of competency development in the hospitality sector is its assessment performed by the coachees' immediate superiors.

Immediate superiors (most often hotel managers or top managers) were asked to assess coaching both in the area of its effects observed in their coached employees, and at the level of hotel functioning.

All the superiors (100\%) noticed competency development in their employees. They were also asked to define identical areas like those coached ones where, in their opinion, coaching proved helpful. 100\% of the superiors whose employees manage their teams noticed that coaching helped the coached employees manage their teams more efficiently (thus contributing to their managerial competencies). The superiors gave the highest marks to the area of the employee's higher self-confidence and capabilities, and communication with other employees. They also stated that in a broader context one can notice better work effectiveness of the team led by a coached employee. There is also better awareness concerning the elements contributing to a coachee's better effectiveness $-90 \%$ to every response. 
Table 3 was drawn to compare coaching assessment performed by coached employees and their immediate superiors.

Table 3. Comparing coaching assessment performed by coached employees and their immediate superiors

\begin{tabular}{|c|c|c|c|}
\hline Particular elements & $\begin{array}{c}\text { Coached } \\
\text { employee's } \\
\text { opinion } \\
\text { (percentage } \\
\text { of cases) }\end{array}$ & $\begin{array}{l}\text { Superior's } \\
\text { opinion } \\
\text { (percentage } \\
\text { of cases) }\end{array}$ & $\begin{array}{c}\text { Difference } \\
\text { (positive result } \\
\text { means an } \\
\text { employees' } \\
\text { higher note) }\end{array}$ \\
\hline More effective management of one's team & 90 & 90 & 0 \\
\hline $\begin{array}{l}\text { More involvement in performing one's } \\
\text { tasks }\end{array}$ & 50 & 60 & -10 \\
\hline $\begin{array}{l}\text { Suggesting ideas to improve work and } \\
\text { hotel/ department functioning }\end{array}$ & 80 & 60 & 20 \\
\hline $\begin{array}{l}\text { More awareness of elements contribut- } \\
\text { ing to the improvement in employee's } \\
\text { efficiency }\end{array}$ & 80 & 90 & -10 \\
\hline $\begin{array}{l}\text { More willingness towards personal } \\
\text { development }\end{array}$ & 70 & 50 & 20 \\
\hline $\begin{array}{l}\text { More confidence in one's strengths and } \\
\text { capabilities }\end{array}$ & 80 & 90 & -10 \\
\hline $\begin{array}{l}\text { Improved communication with other } \\
\text { employees }\end{array}$ & 90 & 90 & 0 \\
\hline More effective team work & 100 & 90 & -10 \\
\hline $\begin{array}{l}\text { Increase in individual work effectiveness } \\
\text { of the coached employee }\end{array}$ & 90 & 70 & 20 \\
\hline $\begin{array}{l}\text { Better customer service performer by } \\
\text { the coached employee }\end{array}$ & 90 & 50 & 40 \\
\hline $\begin{array}{l}\text { Better marks in periodical employee } \\
\text { evaluation }\end{array}$ & 80 & 50 & 30 \\
\hline
\end{tabular}

Source: own research.

As it is presented in Table 3, both the coachees and their superiors' responses concerning "effective team management" and "communication improvement with other employees" are identical. A bit more frequently the effects of coaching were more favourably assessed by coached employees than by their immediate superiors. It can derive from a situation observed in practice, in which employees evaluate themselves more highly (work effects, competencies, behaviour) than their environment does (including their superiors, who are geared towards the realisation of increasingly more difficult goals and tasks).

The above results and the opinions of both coachees and their immediate superiors confirm that although coaching is relatively rarely used 
in the hospitality sector, it develops employees' competencies (answer to the first research question).

\section{DISCUSSION AND CONCLUSION}

In the process of coaching, it is a coachee who looks for answers to posed questions, quite frequently finding them on their own, taking autonomous decisions as a result of coaching and bearing their consequences. This process is undoubtedly more time-consuming than ready-made solutions and recipes that an employee can get from their mentor, or a training participant from their coach, but the taste of success deriving from a coachee's autonomy can give incomparably more satisfaction. Skills acquired on the way of an independent search for the best solutions are remembered longer and become "our" solutions. And this is exactly the strength of coaching. A coachee does not always find the right answer - sometimes they make mistakes, get frustrated and angry. However, finally reaching a given solution gives them a bigger feeling of independence than any other training method. This method contributes to the acquisition and implementation of particular behaviour patterns and it is an opportunity to fight some habits. It is so, as coaching uses the processes of learning and development pertaining to adults. Here lies the answer to the question why coachees regard question posing as an element contributing the most to competency development. Having a coach who not only asks questions, but also listens actively (the second answer) they develop their self-awareness and realise the fact that they actually possess the knowledge, abilities and any resources needed to realise their set goals successfully. It is a crucial motivating factor.

The benefits of coaching marked in the research, deriving from certain competencies development, improve work quality and comfort of hotel employees - not only those participating in the coaching process but their subordinates as well. Coaching is a process in which a coach and a coachee meet at coaching sessions, spend a definite amount of time together, talk a lot and their conversation is characterised by openness, sincerity, and partnership. Coaching teaches how to approach work constructively, how to act and treat other people. Coaching teaches a problem solution approach aimed at reaching the goal: goal setting, defining one's resources, situations and action plan, at the same 
time showing respect and partnership towards people. It should be emphasised that $95 \%$ of the respondents were employees occupying managerial positions. If in 100\% cases coaching contributed to more effective management of one's team (both in their opinion and in the opinion of their immediate superiors), it can be assumed that subordinate employees also felt its positive effects. In their answers to open questions, the respondents stressed development in the areas directly directed to their subordinate employees. Thus, benefits of coaching may be of a "cascading" nature - coaching implemented at higher levels in hotel structures may bring benefits to lower levels as well due to a certain way of thinking and acting characteristic of this method.

The article showed numerous difficulties in the area of HRM in the hospitality sector. Due to the development of defined competencies, coaching may bring positive effects in the area concerning employer-employee conflicts, positively influence atmosphere at work, contribute to the improvement of the sector's image, and consequently decrease difficulties in finding suitable employees. The effects shall be discernible both within the organisation (for employers and employees) and outside (for customers).

\section{LIMITATIONS AND SUGGESTIONS FOR FURTHER RESEARCH}

There are a number of limitations to the present study which should be acknowledged. The first one is the sample size. However, it should be stressed that coaching is a relatively new phenomenon in the hospitality sector. On the other hand, hotels representing the biggest hotel chains in the world participated in the study. Their operating rules, procedures, internal standards (also those concerning the HRM area) are to a lesser or a greater extent similar in various hotels in a given country, quite often even in a bigger geographical area. Moreover, the hospitality sector is characterised by high competitiveness. The time-consuming research process and involving employees representing several levels of hotel structures (coachees, their superiors, quite frequently hotel managers) additionally discouraged from participating in the study.

The other limitation, and at the same time a potential direction of future research, is the lack of final outcomes of coaching from the 
perspective of the employees subordinate to those who participated in the project. It is worth looking for the answers to questions pertaining to the benefits and positive changes noticed by employees whose subordinates developed their competencies of more effective team management. There is a question if subordinate employees noticed more involvement from the side of their subordinates, higher awareness of factors contributing to the growth of employee effectiveness or better communication. Positive evaluation of subordinate employees would be a casting vote in favour of implementing coaching in the hospitality sector.

\section{REFERENCES}

Ainsworth, C. (1995). Strategic human resource planning at Zeneca Pharmaceuticals, Management Development Review, 8(2), 11-15.

Alexander, G. \& Renshaw, B. (2005). Super Coaching. London: Random House.

Anderson, V., Rayner, C. \& Schyns, B. (2009). Coaching at the Sharp End: The Role of Line Managers in Coaching at Work. London: CIPD.

Auerbach, J.E. (2005). Inviting a dialog about core coaching competencies. In: F. Campone \& J.L. Bennett (eds.), Proceedings of the Third International Coach Federation Coaching Research Symposium. Lexington, KY: International Coach Federation.

Barlow, L. (2005). Effective structuring of coaching: using five questions. Development and Learning in Organizations: An International Journal, 19(6), 11-12.

Berge, Z., de Verneil, M., Berge, N., Davis, L. \& Smith, D. (2002). The increasing scope of training and development competency. Benchmarking: An International Journal, 9(1), 43-61.

Bluckert, P. (2005a). Critical factors in executive coaching - the coaching relationship. Industrial and Commercial Training, 37(7), 336-340.

Bluckert, P. (2005b). The similarities and differences between coaching and therapy. Industrial and Commercial Training, 37(2), 91-96.

Boyatzis, R.E. (1982). The Competent Manager: a Model for Effective Performance. New York: John Wiley \& Sons.

Boyatzis, R.E. (2008). Competencies in the $21^{\text {st }}$ century. Journal of Management Development, 27(1), 5-12.

Boyce, L.A., Jackson, R.J. \& Neal, L.J. (2010). Building successful leadership coaching relationships. Journal of Management Development, 29(10), 914-931.

Branch, J. \& Smith, B. (1992). Project-based Management Development: The Volvo Story. Journal of European Industrial Training, 16(1), 3-9. 
Brotman, L.E., Liberi, W.P. \& Wasylyshyn, K.M. (1998). Executive coaching: The need for standards of competence. Consulting Psychology Journal: Practice and Research,50, 40-46.

Clark, D. (1998). Sales mastery training prepares employees for first union's future bank. Journal of Retail Banking Services, 20(2), 35-42.

Crane, T.G. (2001). The Heart of Coaching. San Diego, CA: FTA Press.

Czakon, W. (2011). Zastosowanie studiów przypadków w badaniach nauk o zarządzaniu. In: W. Czakon (ed.), Podstawy metodologii badań w naukach o zarzadzaniu. Warszawa: Wolters Kluwer Business.

Dahling, J.J., Taylor, S., Chau, S.L. \& Dwight, S. (2016). Does coaching matter? A multilevel model linking managerial coaching skill and frequency to sales goal attainment. Personnel Psychology, 69, 863-894.

Day, A. (2010). Coaching at relational depth: A case study. Journal of Management Development, 29(10), 864-876.

Dembkowski, D., Eldridge, F. \& Hunter, I. (2006). The Seven Steps of Effective Executive Coaching. London: Thorogood.

Dickinson, A. \& Ineson, E.M. (1993). The selection of quality operative staff in the hotel sector. International Journal of Contemporary Hospitality Management, 5(1), 16-21.

Eaton, J. \& Brown, D. (2002). Coaching for a change with Vodafone. Career Development International, 7(5), 284-287.

Ellinger, A.D. \& Bostrom, R.P. (1999). Managerial coaching behaviors in learning organizations. Journal of Management Development, 18(9), 752-771.

Evers, W.J.G., Brouwers, A. \& Tomic, W. (2006). A quasi-experimental study on management coaching effectiveness. Consulting Psychology Journal: Practice and Research, 58(3), 174-182.

Graham, H.T. \& Bennett, R. (1998). Human Resources Management. London: Financial Times, Pitman Publishing.

Grant, A.M. (2003). The impact of life coaching on goal-attainment, metacognition and mental health. Social Behavior and Personality, 31, 253-264.

Grant, A.M. (2013). The efficacy of coaching. In: J. Passmore, D.B. Peterson \& T. Freire (eds.), The Wiley-Blackwell Handbook of the Psychology of Coaching and Mentoring. Chichester: John Wiley \& Sons.

Grant, A.M. \& O'Connor, S.A. (2010). The differential effects of solution-focused and problem-focused coaching questions: a pilot study with implications for practice. Industrial and Commercial Training, 42(2), 102-111.

Gravina, N. \& Siers, P. (2011). Square pegs and round holes: Ruminations on the relationship between performance appraisal and performance management. Journal of Organizational Behavior Management, 31(4), 277-287. 
Greif, S. (2013). Conducting organizational-based evaluations of coaching and mentoring programs. In: J. Passmore, D.B. Peterson \& T. Freire (eds.), The Wiley-Blackwell Handbook of the Psychology of Coaching and Mentoring. Chichester: John Wiley \& Sons.

Griffiths, K. (2005). Personal coaching: A model for effective learning. Journal of Learning Design, 1(2), 55-65.

Grobelna, A. (2015). Współczesne problemy zarządzania zasobami ludzkimi w hotelarstwie. Fluktuacja kadr. Logistyka, 3, 1638-1651.

Guest, D. \& King, Z. (2005). Management development and career management. In: S. Bach (ed.), Managing Human Resources. Personnel Management in Transition, $4^{\text {th }}$ edition. Oxford: Blackwell Publishing.

Gupta, O. \& Roos, G. (2001). Mergers and acquisitions through an intellectual capital perspective. Journal of Intellectual Capital, 2(3), 297-309.

Gyllensten, K. \& Palmer, S. (2007). The coaching relationship: an interpretative phenomenological analysis. International Coaching Psychology Review, 2(2), 168-177.

Hannafey, F.T. \& Vitulano, L.A. (2013). Ethics and executive coaching: An Agency Theory Approach. Journal of Business Ethics, 115(3), 599-604.

Henochowicz, S. \& Hetherington, D. (2006). Leadership coaching in health care. Leadership \& Organization Development Journal, 27(3), 183-189.

Hippensteel, B., Larson, A. \& Way, S. (1999). AMCORE achieves higher profits through sales leadership. Journal of Retail Banking Services, 21(1), 39-46.

Hoffmann, T. (1999). The meanings of competency. Journal of European Industrial Training, 23(6), 275-286.

Holbeche, L. (2009). Aligning Human Resources and Business Strategy. Oxford: Elsevier. Hooghiemstra, T. (1992). Integrated management of human resources. In: A. Mitrani, M. Dalziel \& D. Fitt (eds.), Competency Based Human Resource Management. London: Kogan Page.

Hornby, D. \& Thomas, R. (1989). Towards a better standard of management. Personel Management, 21(1), 52-55.

Ives, Y. (2008). What is "coaching"? An exploration of conflicting paradigms. International Journal of Evidence Based Coaching and Mentoring, 6(2), 100-113.

Jarvis, J. (2004). Coaching and Buying Coaching Services. London: CIPD.

Jia, J. \& Fan, L. (2008). Research framework of human resource development based on competency about knowledge enterprises. International Journal of Business and Management, 3(11), 107-111.

Joo, B.K. (2005). Executive coaching: a conceptual framework from an integrative review of practice and research. Human Resource Development Review, 4(4), 462-488. 
Kampa-Kokesch, S. \& Anderson, M.Z. (2001). Executive coaching: A comprehensive review of the literature. Consulting Psychology Journal: Practice and Research, 53(4), 205-228.

Karami, A., Rowley, J. \& Analoui, F. (2006). Research and knowledge building in management studies: An analysis of methodological preferences. International Journal of Management, 23(1), 43-52.

Krazmien, M. \& Berger, F. (1997). The coaching paradox. International Journal of Hospitality Management, 16(1), 3-10.

Latham, G.P. \& Marchbank, T. (1994). Feedback techniques. In: G. Lee \& D. Beard (eds.), Development Centers. Maidenhead, Berks: McGraw-Hill.

London, M. (1997). Job Feedback. Giving, Seeking, and Using Feedback for Performance Improvement. Mahwah, NJ: Lawrence Erlbaum Associates.

Mariampolski, H. (2001). Qualitative Market Research: A Comprehensive Guide. Thousand Oaks: Sage Publications.

Marsh, L. (1992). Good manager: good coach? What is needed for effective coaching? Industrial and Commercial Training, 24(9), 3-8.

Marton, K. \& Pister, K. (2016). Coaching: a useful approach to disruptive behaviour. Physician Leadership Journal, 3(1), 55-57.

Mathis, R.L. \& Jackson, J.H. (2000). Human Resource Management, $9^{\text {th }}$ edition. USA: Thomson Learning.

McClelland, D.C. (1973). Testing for competence rather than for 'intelligence', American Psychologist, 28(1), 1-14.

Mertel, T. (2010). Using meaningful coaching for maximum results. Industrial and Commercial Training, 42(4), 186-191.

Mullins, L.J. (1996). Management and Organizational Behaviour, $4^{\text {th }}$ edition. London: Pitman.

Neumann, J.E. \& Hirschhorn, L. (1999). The challenge of integrating psychodynamic and organizational theory. Human Relations, 52(6), 683-695.

Nielsen, A.E. \& Nørreklit, H. (2011). Self-realisation and control in the discourse practice of management coaching. Employee Relations, 34(2), 159-176.

Oleksyn, T. (2006). Zarzadzanie kompetencjami. Teoria i praktyka. Kraków: Oficyna Ekonomiczna.

Page, S., Brunt, P. \& Connell, J. (2009). Tourism: a Modern Synthesis. Andover: South-West Cengage Learning.

Poulston, J. (2008). Hospitality workplace problems and poor training: a close relationship. International Journal of Contemporary Hospitality Management, 20(4), 412-427.

Pratten, J.D. (2003). The training and retention of chefs. International Journal of Contemporary Hospitality Management, 15(4), 237-242. 
Price, L. (1994). Poor personnel practice in the hotel and catering industry: does it matter? Human Resource Management Journal, 4(4), 44-62.

Rider, L. (2002). Coaching as a strategic intervention. Industrial and Commercial Training, 34(6), 233-236.

Robson, C. (2002). Real World Research. Oxford: Blackwell Publishers Ltd.

Smither, J.W. (2011). Can psychotherapy research serve as a guide for research about executive coaching? An agenda for the next decade. Journal of Business Psychology, 26, 135-145.

Spencer, L.M. \& Spencer, S.M. (1993). Competence at Work. Models for Superior Performance. London: John Wiley \& Sons.

Theeboom, T., Beersma, B. \& van Vianen, A.E.M. (2014). Does coaching work? A meta-analysis on the effects of coaching on individual level outcomes in an organizational context. The Journal of Positive Psychology, 9(1), 1-18.

Ulrich, D. (2008). Coaching for results. Business Strategy Series, 9(3), 104-114.

Wallace, D.P., Van Fleet, C. \& Downs, L.J. (2011). The research core of the knowledge management literature. International Journal of Information Management, 31(1), 14-20.

Wheeler, L. (2011). How does the adoption of coaching behaviours by line managers contribute to the achievement of organisational goals? International Journal of Evidence Based Coaching and Mentoring, 9(1), 1-15.

Whitmore, J. (2009). Coaching for Performance, $4^{\text {th }}$ edition. London: Nicholas Brealey Publishing.

Whitworth, L., Kimsey-House, H., Kimsey-House, K. \& Sandahl, P. (1998). Co-active Coaching: New Skills for Coaching People Toward Success in Work and Life. London: Nicholas Brealey.

Williams, R.S. (2002). Managing Employee Performance. Design and Implementation in Organizastions. London: Thomson Learning.

Wilson, C. (2004). Coaching and coach training in the workplace. Industrial and Commercial Training, 36(3), 96-98.

Woodruffe, C. (1991). Competent by any other name. Personnel Management, 23(9), 30-33.

Woodruffe, C. (1993). What is meant by a competency? Leadership \& Organization Development Journal, 14(1), 29-36.

Yuvaraj, R. (2011). Competency mapping - a Drive for Indian Industries. International Journal of Scientific \& Engeenering Research, 2(8), 1-7.

Zeus, P. \& Skiffington, S. (2001). The Complete Guide to Coaching at Work: The Guide to Business Coaching. Sydney: McGraw Hill.

Zhang Qiu, H. \& Lam, T. (2004). Human resources issues in the development of tourism in China: Evidence from Heilongjiang Province. International Journal of Contemporary Hospitality Management, 16(1), 45-51. 


\section{PROCES COACHINGU ORAZ JEGO WPŁYW NA ROZWÓJ KOMPETENCJI PRACOWNIKÓW W HOTELARSTWIE - CASE STUDY}

\section{Abstrakt}

Tło badań. Coaching w hotelarstwie wykorzystywany jest rzadko. Jest to branża borykająca się z licznymi trudnościami w obszarze zarządzania zasobami ludzkimi. Tymczasem ze względu na specyfikę i wyróżniające elementy tej metody przynosi wiele korzyści.

Cel badań. Pojawiają się zatem pytania: jak często coaching jest wykorzystywany w hotelarstwie? Który z jego elementów (wyznaczanie celów, aktywne słuchanie, zadawanie pytań, udzielanie informacji zwrotnych czy budowanie twórczej atmosfery) ma największy wpływ na rozwój kompetencji? Dodatkowo, z punktu widzenia luki w badaniach naukowych: które kompetencje są rozwijane za pomoca coachingu w hotelarstwie?

Metodologia. W związku z rzadkim stosowaniem coachingu w hotelarstwie wykorzystano case study jako metodę badawcza.

Kluczowe wnioski. Coaching jest rzadko wykorzystywany w hotelarstwie. Najważniejszym jego elementem jest zadawanie przez coacha pytań, które skłaniają do myślenia - zarówno w przeprowadzonych procesach coachingu, jak i wzorcowych. Coaching jest najbardziej pomocny w rozwoju następujacych kompetencji: bardziej efektywne zarządzanie podległym zespołem, komunikacja z pracownikami oraz współpraca zespołowa.

Słowa kluczowe: coaching, kompetencje, rozwój, hotelarstwo. 